\title{
Pemanfaatan Virgin Coconut Oil (VCO) dalam Kehidupan Sehari-Hari di Desa Cemagi Badung Bali
}

\author{
Dewa Ayu Ika Pramitha ${ }^{1}$, Agung Ari Chandra Wibawa ${ }^{2 *}$ \\ ${ }^{1}$ Program Studi Diploma Tiga Farmasi Fakultas Farmasi \\ ${ }^{2}$ Program Studi Sarjana Farmasi Fakultas Farmasi \\ Universitas Mahasaraswati \\ *Corresponding Author Email: agungarichandra@unmas.ac.id
}

\begin{abstract}
This aims of activity to provide education to the public regarding the use and manufacture of Virgin Coconut Oil (VCO) in daily life on a household scale. These activity is in partnership with Cemagi Village, whose daily life usually makes coconut oil from copra (salted oil). The method used in this service is to provide solutions and knowledge, especially in the health sector, regarding the benefits of VCO in everyday life. Participants in this service program are very enthusiastic to accept and carry out every stage of the proposed program. The stages that have been carried out in this service program have helped to increase the knowledge of the Banjar Sangiangan community of Cemagi Village about the process of making VCO and to know the health benefits generated by consuming $\mathrm{VCO}$.
\end{abstract}

Abstrak: Pengabdian ini bertujuan untuk memberikan edukasi kepada masyarakat mengenai pemanfaatan dan pembuatan Virgin Coconut Oil (VCO) dalam kehidupan sehari-hari skala rumah tangga. Kegiatan ini bermitra dengan Desa Cemagi yang keseharian masyarakatnya biasa membuat Minyak kelapa dari kopra (minyak tandusan). Metode yang dilakukan dalam pengabdian ini yaitu memberikan solusi dan pengetahuan khususnya bidang Kesehatan mengenai manfaat VCO dalam kehidupan sehari-hari. Peserta dalam program pengabdian ini sangat antusias untuk menerima dan melaksanakan setiap tahapan dari program yang diusulkan. Tahapan-tahapan yang telah dilaksanakan pada program pengabdian ini telah membantu meningkatkan pengetahuan masyarakat Banjar Sangiangan Desa Cemagi mengenai proses pembuatan VCO dan mengetahui manfaat Kesehatan yang dihasilkan dalam mengkonsumsi VCO.
Article History:

Received: 24-03-2021

Reviewed: 26-04-2021

Accepted: 30-04-2021

Published: 05-05-2021

Key Words:

Coconut, Oil, VCO.

Sejarah Artikel:

Diterima: 24-03-2021

Direview: 26-04-2021

Disetujui: 30-04-2021

Diterbitkan: 05-05-2021

Kata Kunci:

Kelapa, Minyak, VCO.

How to Cite: Pramitha, D., \& Wibawa, A. (2021). Pemanfaatan Virgin Coconut Oil (VCO) dalam Kehidupan Sehari-Hari di Desa Cemagi Badung Bali. Jurnal Pengabdian UNDIKMA, 2(1), 24-29. doi:https://doi.org/10.33394/jpu.v2i1.3743

doi:https://doi.org/10.33394/jpu.v2i1.3743

This is an open-access article under the CC-BY-SA License.

\section{Pendahuluan}

Indonesia merupakan negara yang kaya dengan hasil perkebunannya. Salah satu jenis dari hasil perkebunan yang ada di Indonesia dan paling potensial adalah pohon kelapa. Pohon kelapa (Cocos nucifera L.) merupakan tanaman yang bermanfaat bagi kehidupan manusia. Hampir seluruh bagian dari pohon kelapa dapat digunakan untuk memenuhi kebutuhan. Bagian terpenting dari pohon kelapa adalah air dan daging buah kelapa. Daging buah kelapa adalah salah satu bagian dari kelapa yang sering digunakan oleh masyarakat maupun industri.

Dalam pemanfaatannya, daging buah kelapa dapat diolah menjadi kopra kemudian diproses lebih lanjut menjadi minyak. Daging buah kelapa dipergunakan juga dalam keadaan segar sebagai santan, kelapa parut, maupun untuk pembuatan minyak. Minyak kelapa 
memiliki kandungan asam lemak yaitu diantaranya asam lemak jenuh yang diperkirakan $91 \%$ terdiri dari Kaproat, kaprilat, kaprat, laurat, miristat, Palmatic, stearat, dan asam lemak tak jenuh sekitar 9\% yang terdiri dari Oleat dan Linoleic (Warisno, 2003)

Seiring dengan perkembangan, masyarakat mulai membuat minyak kelapa dengan metode fermentasi alami yakni pembuatan minyak kelapa dengan cara membuat krim santan dan didiamkan kurang lebih 10-14 jam. Proses fermentasi akan berjalan dengan baik jika terbentuk tiga lapisan, yakni lapisan atas berupa minyak, lapisan tengah berupa blondo (coconut milk proteins) dan lapisan bawah berupa air (Agarwal, 2017). Lapisan minyak dipisahkan secara hati-hati. Minyak ini memberi aroma khas dan warna yang lebih jernih. Lapisan minyak yang terbentuk merupakan minyak murni yang sering disebut dengan Virgin Coconut Oil (VCO).

VCO (Virgin Coconut Oil) atau non-kopra adalah minyak murni yang dibuat tanpa pemanasan menggunakan daging buah kelapa segar. Minyak ini tidak berwarna dan mempunyai aroma yang harum dan khas, sering dijadikan bahan baku industri pangan, kosmetika, dan farmasi, selain itu minyak ini mempunyai kandungan asam laurat yang sangat tinggi (45-55\%). Pada penelitian Widjaja, et al (2015) dengan menambahkan enzim papain dan bromealin, masing-masing memiliki kadar air $0 \%$ serta bilangan peroksida $0,443 \pm 0,120$ (enzim papain) dan 1,068 $\pm 0,53$ (enzim bromealin). Mutu VCO harus memenuhi standar yakni memiliki bau khas kelapa segar, tidak tengik, dengan rasa yang khas seperti kelapa, dan memiliki warna yang bening hingga kuning pucat serta memiliki kadar air maksimal 0,2 \% . Selain itu, berdasarkan persyaratan SNI, minyak dinyatakan berkualitas jika memiliki nilai bilangan peroksida kurang dari $2 \mathrm{mg}$ ek/kg. (SNI, 2008).

Penggunaan VCO di masyarakat semakin meningkat seiring dengan meningkatnya perkembangan pengobatan yang berbasis back to nature dengan bahan-bahan yang berasal dari alam. VCO yang terhidrolisis memiliki kemampuan sebagai antibakteri (Silalahi et al., 2014), hepatoprotektif (Zakaria et al., 2011), dan sebagai pencegah pro-oksidan yang dapat memediasi kematian sel (Illam et al., 2017).

VCO sudah banyak dimanfaatkan dalam dunia industri sebagai bahan baku produk pada industry farmasi, makanan, dan kosmetika. VCO memiliki keamampuan sebagai antioksidan dengan dosis $10 \mathrm{ml} / \mathrm{kg}$ berat badan dapat menurunkan stress oksidatif pada beberapa hewan coba tikus yang telah direnangkan. Pada penelitian ini juga menunjukan setelah pemberian VCO pada hewan coba tikus dapat menurunkan kadar kolesterol, trigliserid, glukosa dan kortiskosteron (Yeap et al., 2015).

Penelitian yang dilakukan Famurewa \& Ejezie (2018) dengan mengisolasi senyawa polifenol pada VCO berpotensi sebagai pencegahan risiko terjadinya kardiovaskuler pada hewan coba tikus. Kandungan polifenol dari VCO yaitu sebanyak 61,22 $\pm 2,34 \mathrm{mgGAE} / 100 \mathrm{~g}$ dapat menurunkan stress oksidatif dan peradangan saraf (neuro-inflammation) pada tikus yang diinduksi methotrexate (MTC) (Ademola C. Famurewa et al., 2019).

Dengan demikian perlu dilakukan edukasi kepada masyarakat tentang proses pembuatan VCO dan manfaat Kesehatan yang diberikan oleh VCO. Hal ini sejalan dengan upaya-upaya pemerintah dalam menjaga kelestarian dan pengembangan kekayaan alam, maka upaya ini harus didukung oleh seluruh lapisan masyarakat. Menurut hasil wawancara dengan pemuka masyarakat setempat, banyak penduduk Desa Cemagi yang biasa membuat Minyak kelapa yang dibuat dari kopra (biasa disebut minyak tandusan). Proses pembuatan minyak tandusan ini biasa dibuat dengan proses pemanasan. Masih banyak warga yang belum mengetahui bahwa proses pembuatan minyak kelapa dapat pula dengan cara fermentasi alami yang memiliki manfaat lebih banyak. Selain dalam bentuk edukasi, sebagai percontohan 
aplikasi dari VCO yang dibuat, diberikan salah satu produk hasil olahan dengan VCO kepada masing-masing ibu PKK yang ada di Desa Cemagi, Kecamatan Mengwi, Kabupaten Badung, Provinsi Bali.

\section{Metode Pengabdian}

Metode yang digunakan dalam kegiatan pengabdian ini yaitu memberikan solusi dalam menjawab permasalahan yang ada di masyarakat sekaligus memberikan pengetahuan terutama dalam bidang Kesehatan mengenai manfaat VCO. Solusi yang ditawarkan untuk menjawab permasalahan mitra adalah :

(1) Solusi untuk menjawab permasalahan kurangnya pengetahuan masyarakat akan manfaat Virgin Coconut Oil (VCO) dalam rumah tangga.

Upaya meningkatkan pengetahuan masyarakat akan manfaat Virgin Coconut Oil (VCO) dalam rumah tangga untuk mengembangkan pelestarian obat tradisional akan diadakan penyuluhan yang dirangkaikan dengan diskusi menggunakan metode Community Based Interaktive Approach Method atau Metode Cara Belajar Insan Aktif (CBIA). Diskusi dilaksanakan menurut langkah berikut : (1) Masyarakat yang hadir dikelompokkan dengan satu kelompok terdiri dari 6-8 orang disesuaikan dengan jumlah peserta yang hadir. (2) Setiap anggota kelompok kecil ini diberi beberapa jenis minyak berbeda, setelah itu mereka diberi tugas untuk menyebutkan nama minyak dan manfaatnya dari masing-masing minyak yang diberikan. Setiap kelompok dibantu oleh fasilitator, sehingga diskusi dan tujuan pemahaman mengenai VCO tepat sasaran. Metode CBIA mengarahkan pada proses belajar aktif dan interaktif berbasis komunitas. Standar efektivitas program dapat dinilai dengan membandingkan pra-test dan post-test. Dengan metode CBIA, diharapkan masyarakat bisa mengetahui manfaat VCO dan menggunakannya sesuai kebutuhan.

(2) Solusi untuk menjawab permasalahan skill masyarakat Desa Cemagi mengenai cara pemanfaatan dan pembuatan Virgin Coconut Oil (VCO) dalam skala rumah tangga

Akan dilakukan simulasi pembuatan minyak rambut dengan bahan dasar VCO ditambahkan kemiri dan bunga kenanga sebagai salah satu pemanfaatan dari VCO. Selain itu, diberikan pula pemaparan mengenai proses pembuatan dari VCO agar ibuibu PKK desa mengetahui proses pembuatan VCO dalam skala rumah tangga dan lebih berminat untuk membuat VCO sendiri. Setelah mendapatkan ibu-ibu akan dicari anggota PKK desa yang berminat untuk diberikan pelatihan proses pembuatan Virgin Coconut Oil (VCO) skala rumah tangga di Desa Cemagi, Kecamatan Mengwi, Kabupaten Badung. Pelatihan ini nantinya akan dikelola oleh kader PKK Desa Cemagi untuk menjamin keberlanjutannya. Produk olahan dari VCO akan disumbangkan dengan harapan dapat dijadikan percontohan produk aplikasi dari VCO, sehingga tujuan pengabdian masyarakat untuk mengedukasi masyarakat agar dapat membuat dan memanfaatkan VCO dengan baik dalam rumah tangga.

\section{Hasil Pengabdian dan Pembahasan}

Pengabdian kepada masyarakat mengenai sosialisasi pemanfaatan Virgin Coconut Oil (VCO) dalam kehidupan sehari-hari pada warga Desa Cemagi. Pengabdian dilakukan pada tahun 2019 yang berlokasi Desa Cemagi, Kecamatan Mengwi, Kabupaten Badung, Provinsi Bali. Lokasi pengabdian kepada masyarakat terlihat pada Gambar 1. Peserta terdiri dari anggota PKK Desa Cemagi beserta pengurus PKK Desa Cemagi, Sekretaris Desa Cemagi, 
pelaksana, pembicara, fasilitator, serta mahasiswa Fakultas Farmasi Universitas Mahasaraswati Denpasar.

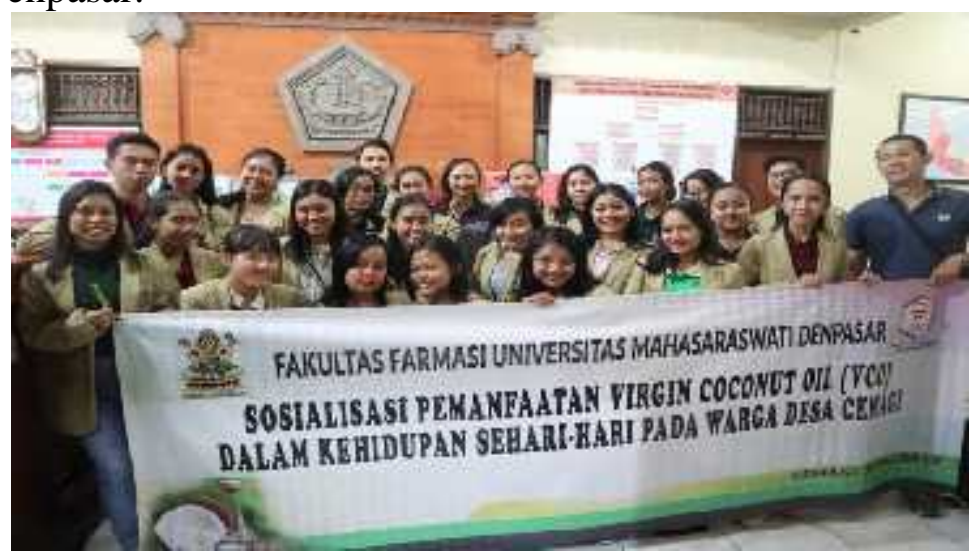

Gambar 1. Pengabdian Masyarakat di Kantor Desa Cemagi

Tahapan kegiatan yang telah dilaksanakan meliputi penyuluhan dan diskusi menggunakan metode CBIA untuk meningkatkan pemahaman masyarakat tentang pemanfaatan Virgin Coconut Oil (VCO) dalam kehidupan sehari-hari. Dalam pelaksanaan juga dilakukan metode pretest dan posttest untuk menilai keefektifan program. Sebelum kegiatan peserta diberikan kuesioner untuk mengetahui pemahaman masyarakat mengenai VCO, setelah kegiatan pula diberikan kuesioner kembali. Dengan membandingkan hasil pretest dan posttest maka pelaksana dapat menilai efektifvitas program. Pada tahap diskusi peserta diajak untuk menggali sendiri pengetahuan yang harus mereka kuasai dengan dipandu oleh fasilitator. Fasilitator adalah dosen-dosen dari Fakultas Farmasi Universitas Mahasaraswati. Fasilitator bertugas untuk membantu anggota kelompok dalam menentukan jenis minyak yang dibagikan dan memberikan arahan untuk menuliskan nama jenis minyak dan menuliskan manfaat serta cara pemanfaatannya. Dalam proses diskusi, peserta dibagi menjadi 6 kelompok yang dipandu oleh fasilitator. Fasilitator membantu peserta dalam kelompok untuk menunjukkan beberapa jenis minyak. Peserta diminta untuk menentukan jenis minyak, menuliskan nama minyak dan menuliskan manfaat serta cara pemanfaatan dari masing-masing minyak yang telah dibagikan dan melakukan diskusi seperlunya dengan fasilitator. Setelah diskusi, peserta yang menjadi responden diminta untuk mengisi kuesioner kembali sebagai posttest. Berikut ini scara berturut-turut data demografi sampel uji peserta puntuk tingkat Pendidikan (Gambar 2), untuk pekerjaan responden (Gambar 3) dan untuk umur responden (Gambar 4).

\section{Tingkat Pendidikan}
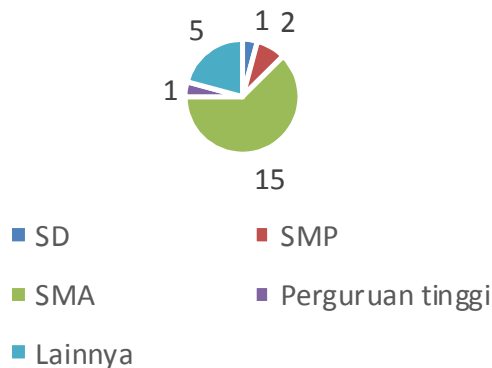

Gambar 2. Diagram Tingkat Pendidikan Responden 


\section{Pekerjaan Responden}

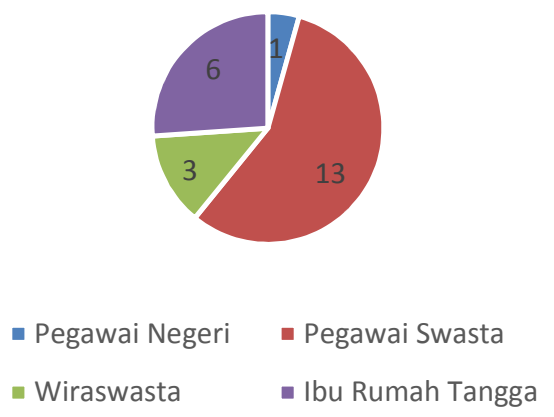

\section{Umur Responden}

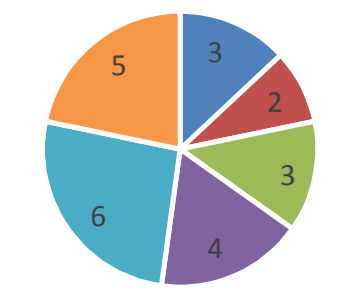

- 30 tahun $=31$ tahun $=35$ tahun

- 37 tahun $=42$ tahun $\approx 45$ tahun

Gambar 3. Diagram Pekerjaan Responden Gambar 4. Diagram Umur Responden

Kuesioner pemahaman peserta terhadap pengabdian VCO terbagi atas dua jenis pertanyaan, yaitu pertanyaan tentang data diri, dan pertanyaan terkait pengetahuan responden. Pertanyaan yang digunakan untuk menilai efektifitas program yaitu pernyataan pengetahuan. Hasil analisis kuesioner yang telah disebarkan dapat dijabarkan pada Tabel 1.

\begin{tabular}{cccc} 
Tabel 1. Hasil Analisis Data & Pengetahuan Responden \\
\hline Pertanyaan & Hasil pretest & Hasil post test & Selisih \\
\hline $\mathbf{1}$ & 3 & 20 & 17 \\
$\mathbf{2}$ & 5 & 23 & 18 \\
$\mathbf{3}$ & 1 & 1 & 0 \\
$\mathbf{4}$ & 3 & 22 & 19 \\
$\mathbf{5}$ & 6 & 23 & 17 \\
$\mathbf{6}$ & 3 & 23 & 20
\end{tabular}

Berdasarkan Tabel diatas, terlihat bahwa adanya peningkatan pengetahuan responden terhadap pemanfaatan virgin coconut oil (VCO) sebagai produk kesehatan pada pertanyaan 1 , 2, 4, 5, dan 6. Pertanyaan nomor 3, menyatakan bahwa responden tidak pernah mengkonsumsi VCO dalam kehidupan sehari-hari. Hal ini dapat menunjukkan bahwa responden telah memahami manfaat dan proses pembuatan Virgin Coconut Oil (VCO) dalam rumah tangga.

\section{Kesimpulan}

Kesimpulan yang diperoleh dari program pengabdian kepada masyarakat ini adalah (1) Peserta dalam program pengabdian ini sangat antusias untuk menerima dan melaksanakan setiap tahapan dari program yang diusulkan dan mengharapkan bahwa program seperti ini tidak hanya dilakukan sekali, melainkan dapat dilakukan secara berkesinambungan, (2) Tahapan-tahapan yang telah dilaksanakan pada program pengabdian ini telah membantu meningkatkan pengetahuan masyarakat Banjar Sangiangan Desa Cemagi tentang proses pembuatan VCO dan mengetahui manfaat yang diberikan oleh VCO itu sendiri dapat tercapai. 


\section{Saran}

Adapun saran yang disampaikan berdasarkan hasil kegiatan pengabdian ini adalah perlu dilakukan kerjasama dengan beberapa pihat terkait, baik pemerintah maupun swasta sehingga mampu memperluas sasaran program.

\section{Daftar Pustaka}

Agarwal, R. K. (2017). Extraction Processes of Virgin Coconut Oil. MOJ Food Processing \& Technology, 4(2). https://doi.org/10.15406/mojfpt.2017.04.00087

Famurewa, Ademola C., Aja, P. M., Nwankwo, O. E., Awoke, J. N., Maduagwuna, E. K., \& Aloke, C. (2019). Moringa oleifera seed oil or virgin coconut oil supplementation abrogates cerebral neurotoxicity induced by antineoplastic agent methotrexate by suppression of oxidative stress and neuro-inflammation in rats. Journal of Food Biochemistry, 43(3), 1-10. https://doi.org/10.1111/jfbc.12748

Famurewa, Ademola Clement, \& Ejezie, F. E. (2018). Polyphenols isolated from virgin coconut oil attenuate cadmium-induced dyslipidemia and oxidative stress due to their antioxidant properties and potential benefits on cardiovascular risk ratios in rats. Avicenna Journal of Phytomedicine, 8(1), 73-84. https://doi.org/10.22038/ajp.2017.23544.1869

I N.K., Widjaja, N.K., Warditiani, N.M.P., Susanti,, L.P.F., L. (2015). Rendemen VCO (Virgin Coconut Oil) yang Diperoleh dengan Penambahan Enzim Papain dan $\begin{array}{llll}\text { Bbromealin. Jurnal } & \text { Farmasi }\end{array}$ http://ojs.unud.ac.id/index.php/jfu/article/view/17126\%0A

Illam, S. P., Narayanankutty, A., \& Raghavamenon, A. C. (2017). Polyphenols of virgin coconut oil prevent pro-oxidant mediated cell death. Toxicology Mechanisms and Methods, 27(6), 442-450. https://doi.org/10.1080/15376516.2017.1320458

Silalahi, J., Yademetripermata, \& Putra, E. de L. (2014). Antibacterial activity of hydrolyzed virgin coconut oil. Asian Journal of Pharmaceutical and Clinical Research, 7(SUPPL. 2), 90-94.

SNI 7381. 2008. Minyak Kelapa Virgin (VCO). Badan Standarisasi Nasional. ICS 67.200.10

Warisno, 2003, "Budidaya Kelapa Genjah". Kanisius. Yogyakarta. hal 15-16.

Yeap, S. K., Beh, B. K., Ali, N. M., Yusof, H. M., Ho, W. Y., Koh, S. P., Alitheen, N. B., \& Long, K. (2015). Antistress and antioxidant effects of virgin coconut oil in vivo. Experimental and Therapeutic Medicine, 9(1), 39-42. https://doi.org/10.3892/etm.2014.2045

Zakaria, Z. A., Rofiee, M. S., Somchit, M. N., Zuraini, A., Sulaiman, M. R., Teh, L. K., Salleh, M. Z., \& Long, K. (2011). Hepatoprotective activity of dried- and fermentedprocessed virgin coconut oil. Evidence-Based Complementary and Alternative Medicine, 2011. https://doi.org/10.1155/2011/142739 